\title{
Impact of Air Pollution on Community's Health, Evidence of Industrial Zone in Masoro, Ndera Sector, Rwanda
}

\author{
Kagame Tonny, Nsanzumukiza Martin Vincent*, \\ Mucyo Jean Claude, Maniragaba Abias, \\ Akimanizanye Victoire, Nsengimana Janvier
}

Department of Environmental Economics and Natural Resources Management, Faculty of Environmental Studies, University of Lay Adventists of Kigali, Kigali, Rwanda

Email: *nsanzumumartiv@gmail.com

How to cite this paper: Tonny, K., Vincent, N. M., Claude, M. J., Abias, M., Victoire, A., \& Janvier, N. (2020). Impact of Air Pollution on Community's Health, Evidence of Industrial Zone in Masoro, Ndera Sector, Rwanda. Journal of Geoscience and Environment Protection, 8, 47-60.

https://doi.org/10.4236/gep.2020.86005

Received: May 7, 2020

Accepted: June 26, 2020

Published: June 29, 2020

Copyright $\odot 2020$ by author(s) and Scientific Research Publishing Inc. This work is licensed under the Creative Commons Attribution International License (CC BY 4.0).

http://creativecommons.org/licenses/by/4.0/

(c) (i) Open Access

\begin{abstract}
Air pollution is among the leading global risks for mortality and responsible for increasing risk for chronic diseases. The aim of this study was to explore the impact of industrial zone air pollution on Masoro community and identify some health problems which are experienced in the communities. The key informants were selected using a purposive sampling technique and random sampling based on polluted areas. During this research, Kibagabaga hospital was consulted to identify different illness associated with air pollution in Ndera industrial zone. Respondents illustrated that a great part of emission came from industry, related activities and vehicles. The findings from the hospital illustrated that the respiratory, hypertension and diabetes dominated the illness in community due to air pollution from industrial zone, which was confirmed in this research with reference to the survey results. Air pollution is one of the greatest environmental threats and has been implicated for several adverse cardiovascular effects including arterial hypertension and diabetes. Air contamination provokes oxidative stress, systemic inflammation, and autonomic nervous system imbalance that subsequently induce endothelial dysfunction and vasoconstriction leading to increased blood pressure. The respondents confirmed that the communities are aware of pollution and experienced the consequences of pollution such as cancer and other complicated illness.
\end{abstract}

\section{Keywords}

Air Pollution, Community Heath, Effect of Air Pollution, Industrial Zone 


\section{Introduction}

Air pollution is one of many environmental challenges confronting the world today; Public anxiety over the possible adverse health impacts of air pollution has increased over the years which directed at the possible connection between air pollution and different illness especially those of respiratory disease (Scott \& Diab, 2000; Kim, Kabir et al., 2015; Bai, Guan et al., 2016). This increase in environmental awareness since the 1980s coincided with a time of political and social transformation in Africa's history (Hunter, Davies et al., 2003). Growth and concentration of the population in cities, as well as the way in which energy is consumed in urban areas through transport or heating and air conditioning systems, among others, result in the emission of huge quantities of gases that are harmful to our health (Roemer-Mahler, 2006).

The concentration of particulate matter (PM) is a key air quality indicator since it is the most common air pollutant that affects short term and long term health (Kim, Kabir et al., 2015). The particulate matter is used to analyze air quality; fine particles with a diameter of less than $2.5 \mu \mathrm{g}$ or $\mathrm{PM}_{2.5}$ and coarse particles with a diameter of less than $10 \mu \mathrm{g}$ or $\mathrm{PM}_{10}$. $\mathrm{PM}_{2.5}$ particles are more dangerous due to their small size which allows them to travel deeper into the cardiopulmonary system (Nel, 2005). World wide's economic development has increased rapidly due to industrial development. However, economic development comes at the cost of deterioration of the environment (Kan, Chen et al., 2009).

In Rwanda, industrial sector is growing and its contributions are ranked to $14 \%$ of GDP (Kamarudeen \& Söderbom, 2013); across the country, industry is located, especially in Ndera in Gasabo district which is a special economic industrial zone. The monitoring of pollutants $\left(\mathrm{SO}_{2}, \mathrm{O}_{3}, \mathrm{CO}, \mathrm{NO}_{x}, \mathrm{PM}_{2.5}\right)$ indicates that Particulates $\left(\mathrm{PM}_{10}, \mathrm{PM}_{2.5}\right)$ and Oxides of nitrogen $\left(\mathrm{NO}_{\mathrm{x}}\right)$ are currently the main pollutants of concern in Rwanda (Nsengimana, Bizimana et al., 2011; Henninger, 2013). In recent years, there have been increasing public concerns about the potential impact of air pollution on health in Rwanda, which has been reflected in many epidemiological issues (Pope III, Burnett et al., 2004). Without a greater sensitivity to the everyday contexts in which individuals and collective understandings are set; appeals to individual action are likely to fall on deaf ears (Bickerstaff \& Walker, 2003).

Pollution related disease has been manifested in different forms in Rwanda due to the presence of industry nearby the community. Kigali city especially special economic zone, might appear different emission of pollutants which can affect the air quality and this incites the increase of environmental destructions which reflect in different human illness especially those of cancer, respiratory and cardiovascular disease in Rwanda. This paper aimed to assess the impact of air pollution from industrial zone to Ndera' community livelihood in Gasabo district. Hence, the novelty of this report is related to the investigation of impact of air pollution on the population which lives near industrial zone through the collection of evidence from the hospital and the information provided with respondents. 


\section{Materials and Methods}

\subsection{Study Areas Description}

Gasabo district is one of four district of Kigali city. The study area is located in Ndera sector which is one of the 15 sectors of Gasabo district. Ndera sector hubs different industries which contribute much of air pollution in surrounding community. In Figure 1, the study area is clearly shown in grey color. The Masoro cell is the main study areas due to its location in which big part of the industrial zone is located. The communities around the industrial zone are reported to be affected with the air pollution with respect to the activities performed; this pushed the ideas of selecting this area to investigate impact of air pollution to Masoro communities

The industrial zone in Ndera sector is located mainly in Masoro cell and its small part extends to Musave cell (Figure 1). The population near industrial zone have been expropriated and relocated. The small communities still live in surroundings of Masoro and Musave cell.

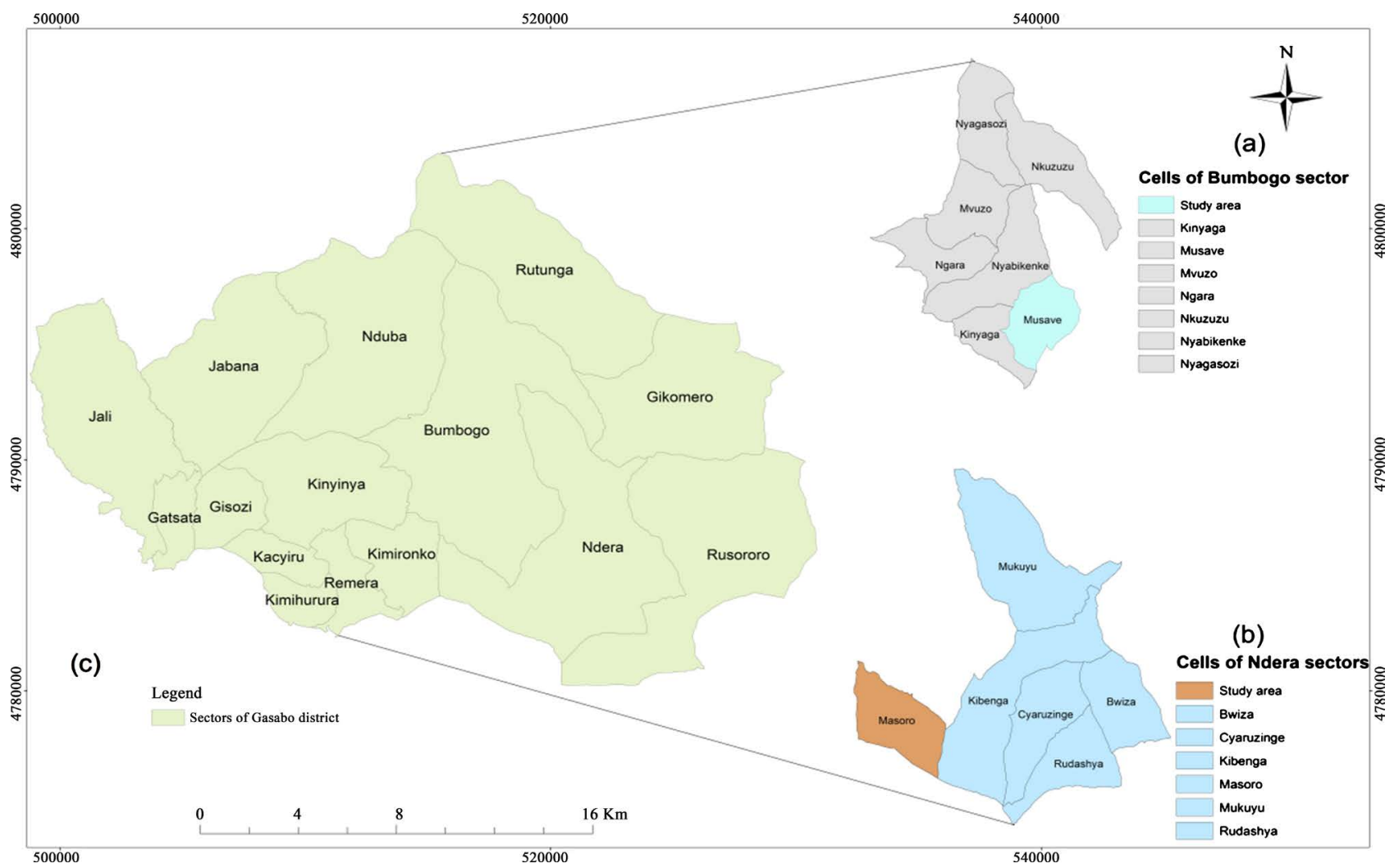

Figure 1. Mapp indicating the location of study areas (a) Masoro cell in Ndera sector, (b) Musave cell in Bumbogo sector and (c) Sectors of Gasabo district neighboring the study area.

\subsection{Sample and Data Collection Techniques}

Kibagabaga hospital was visited to collect the information relating to the frequent of patients affected with the air pollution in Masoro cell in Ndera sector. Hospital admissions data of patients affected with respiratory and other related 
illnesses were collected from 2000 to 2020. Kibagabaga hospital is one hospital nearby the study areas. In the study areas, the population of 696 , which represent the population left in the surrounding areas of the industrial zone after expropriation and the key informants from five different institutions related to pollution management were approached for key information collection (Table 1). To select the sample size among the population in surrounding areas of industry, Equation (1) was previously used in different research (Slovin, 1960; Azumah, Donkoh et al., 2018; Uwayo, Nsanzumukiza et al., 2020). Equation (1) helps to ascertain the sample of a given population of the study.

$$
n=\frac{N}{1+N(e)^{2}}
$$

where $n$ is the sample size, $e$ is the margin of error (which is 0.05 with confidence level of $95 \%) . N$ is the population, which is 696 . By substitution, the sample size $(n)$ is computed as 279 (Table 1 ). Table 1 shows the targeted population and the sample size.

The questionnaire instrument was used to collect data from the selected population (Table 1).

Table 1. Targeted population and sample size.

\begin{tabular}{cccc}
\hline Group of respondents & Targeted population & Percentage (\%) & Sample size \\
\hline Gasabo district staff & 25 & 3.61 & 9 \\
Industry staff & 33 & 4.74 & 12 \\
Rema staff & 14 & 2.01 & 5 \\
RTDA staff & 27 & 3.87 & 10 \\
RBC staff & 17 & 2.44 & 6 \\
Masoro cell population & 580 & 83.33 & 237 \\
Total & 696 & 100 & 279 \\
\hline
\end{tabular}

\section{Results and Discussion}

\subsection{Demographic Characteristics of Respondents}

Table 2 shows the characteristics of the participants (age, sex, education, and status). Most were married (43.36\%) and had finished elementary school (18.99\%) or middle school (45.87\%); only $35.14 \%$ had attended college or university.

This indicates that people are aware of pollution and its impact on human health. Children and elders are vulnerable people in community, as highlighted by previous research which linked negative effect of air pollution among the elder and early childhood (Ajayi, Akinnifesi et al., 2007; Ashmore \& Dimitroulopoulou, 2009; Gül, Gaga et al., 2011; Bowatte, Lodge et al., 2015; Khafaie, Yajnik et al., 2016), this study indicated that $19 \%$ of the people living around Masoro industrial zone, with the age greater than fifty are vulnerable to pollution (Table 2). 
Table 2. Demographic characteristics of respondents.

\begin{tabular}{|c|c|c|c|c|}
\hline Demographic characteristic & Sample size (279) & Frequency & Percent & $p=$ Value \\
\hline \multirow{7}{*}{ Age of respondents } & $>25$ years & 12 & 64.0 & $1.31 \times 10^{-3}$ \\
\hline & 25 - 30 years & 39 & 13.97 & \\
\hline & $30-40$ years & 111 & 39.79 & \\
\hline & 40 - 50 years & 63 & 22.58 & \\
\hline & $>50$ & 54 & 19.36 & \\
\hline & Total & 279 & 100 & \\
\hline & Single & 31 & 11.11 & 0.173 \\
\hline \multirow{4}{*}{ Status of respondents } & Married & 121 & 43.36 & \\
\hline & Divorced & 12 & 4.30 & \\
\hline & Widower & 79 & 28.31 & \\
\hline & Separated & 36 & 12.92 & \\
\hline \multirow{6}{*}{ Education background } & Total & 279 & 100.0 & \\
\hline & Primary & 53 & 18.99 & 0.891 \\
\hline & A'level & 128 & 45.87 & \\
\hline & Bachelor & 64 & 22.93 & \\
\hline & masters & 24 & 8.60 & \\
\hline & $\mathrm{PhD}$ & 10 & 3.61 & \\
\hline \multirow{4}{*}{ Gender of respondents } & Total & 279 & 100 & \\
\hline & Female & 126 & 45.16 & 0.0346 \\
\hline & male & 153 & 54.84 & \\
\hline & Total & 279 & 100.0 & \\
\hline
\end{tabular}

The age influences persistence of air pollution effect on individual in community, when considering age of people, cough and other symptoms persists according to the recorded information (Table 2). The respondents confirmed that such aged and childhood are significantly impacted by the emission level (Salvi, 2007; Ashmore \& Dimitroulopoulou, 2009).

\subsection{Occurrence of Respiratory Disease Symptom in Masoro Community}

The symptom as the response of being exposed to air pollution has been reported by respondents (Table 3 ). There is clear evidence that the air pollution from industrial zone is associated with cardiopulmonary and respiratory disease (Table 3). The investigation conducted in this study indicated that the number of patients from the affected area, which have visited nearby hospital (Kibagabaga Hospital), and recorded results, showed that some of the patients presented sign of respiratory and cardiovascular disease (Table 3). Previous research reported that people living in polluted areas had a higher risk of hospital visits 
Table 3. Perception of respondents about the health problems experienced.

\begin{tabular}{cccccccc}
\hline & \multicolumn{2}{c}{ Disagree, } & \multicolumn{2}{c}{ Neutral } & \multicolumn{3}{c}{ Agree } \\
\cline { 2 - 7 } Parameters & Frequency & $\%$ & Frequency & $\%$ & Frequency & $\%$ \\
\hline $\begin{array}{c}\text { Respiratory and cardiovascular disease } \\
\text { (Cough/Cold, high blood pressure) }\end{array}$ & 33 & 13.8 & 9 & 3.7 & 195 & 82.22 \\
Issued reproductive dysfunction & 157 & 66.2 & 7 & 2.9 & 73 & 59.1 \\
Irritation of eye & 17 & 47.17 & 4 & 1.6 & 216 & 91.08 \\
Liver, lung and spleen issue & 12 & 5.23 & 12 & 5.06 & 233 & 89.87 \\
Cancer challenges & 158 & 66.6 & 25 & 10.54 & 54 & 22.78 \\
CNS and hematologic dysfunctions & 63 & 26.56 & 8 & 3.37 & 166 & 70 \\
\hline
\end{tabular}

related to respiratory diseases than people living in the less polluted areas (Patel, Ramaiah Nellore et al., 2008). It is well known that air pollution causes cardiovascular disease (Cohen, Ross Anderson et al., 2005; Zhang, Wang et al., 2011), mental disorders (Wong, Ou et al., 2008; Zhang, Li et al. 2011; Zhang, Wang et al., 2011), respiratory diseases (Zhang, Li et al., 2011) and emergency hospital visits of mental stress have been growing (Figure 2). Recently, evidence has indicated that nitric oxide $\left(\mathrm{NO}_{2}\right)$, particulate matter $\left(\mathrm{PM}_{10}\right)$, sulphur dioxide $\left(\mathrm{SO}_{2}\right)$, and other air pollutants trigger acute adverse effects on the human circulatory system (Liu, Chen et al., 2015). Previous research found an increases of respiratory hospital admissions related to $\mathrm{PM}_{2.5}$ (Neuberger, Moshammer et al., 2013). Health consequences of air pollution are of different range from irritation of the eyes (Ghorani-Azam, Riahi-Zanjani et al., 2016) and severe respiratory disease to chronic respiratory disease (Gao, Chan et al., 2014), heart disease and lung cancer (Pope III, Burnett et al., 2011). The eyes are most vulnerable to the impact of air pollution through the direct exposure to air pollution and. Previous research reported of corneal drying (Saxena, Srivastava et al., 2003; Gupta, Gupta et al., 2007), irritation and itching in the eyes to people who were exposed traffic pollution (Gupta, Gupta et al., 2007; West, Bates et al., 2013). Table 3 indicated that the respondents experienced the health problem in Ndera community and findings revealed that $82.22 \%$ of respondents were vulnerable to respiratory (Table 4) and cardiovascular disease, (Cough/Cold, high blood pressure), 30.7\% of respondent were agreed that they face reproductive dysfunction in the area around the industry zone. The respondents indicated that the air pollution is associated with challenge of reproductive dysfunction, however, there is no scientific evidence which correlated the issue with reproductive dysfunction, and previous research illustrated that impairment of reproduction in male maybe correlated to the exposure to inorganic lead (Kumar, 2004). The $91.08 \%$ percentage of respondents reported the eye Irritation due to the air pollution in their community.

Previous research illustrated that the redness and irritation of the eyes are considered to be the immediate effect of exposure to toxic fumes (Gupta, Gupta et al., 2002), frequency of ocular irritation and tear film instability, some eyes 
Table 4. Respiratory and other infectious disease recorded in Masoro community, Ndera sector.

\begin{tabular}{|c|c|c|c|c|c|c|c|c|c|}
\hline Data/Period & 2012 & 2013 & 2014 & 2015 & 2016 & 2017 & 2018 & 2019 & 2020 \\
\hline Skin Infection Fungal-Mycoses-Superficial-OPD & 69 & 0 & 0 & 0 & 0 & 0 & 54 & 59 & \\
\hline Skin Infection Fungal-Mycoses-Superficial-OPDDH & & 3 & 0 & 7 & 8 & 11 & 7 & 2 & \\
\hline Skin Infection Scabies-OPD & 67 & 0 & 0 & 0 & 0 & 0 & 77 & 427 & \\
\hline Skin Infection Scabies-OPDDH & & 5 & 0 & 0 & 0 & 0 & 2 & 3 & \\
\hline Skin Infections Other-OPD & 734 & 901 & 966 & 347 & 250 & 172 & 343 & 235 & \\
\hline Skin Infections Other-OPDDH & & 6 & 38 & 4 & 0 & 21 & 14 & 4 & \\
\hline Ulcers of Skin & 60 & 0 & 0 & 0 & 0 & 0 & 4 & 43 & \\
\hline Respiratory Infections Acute Other OPD & 5290 & 8799 & 11,067 & 15,432 & 17,020 & 18,986 & 10,126 & 6277 & \\
\hline Respiratory Infections Acute Other-OPDDH & & 9 & 4 & 2 & 1 & 79 & 50 & 87 & \\
\hline Ear Infections & 190 & 124 & 164 & 153 & 33 & 98 & 361 & 110 & \\
\hline Ear Infections-OPDDH & & 6 & 9 & 0 & 0 & 3 & 3 & 8 & \\
\hline Urinary Tract Infections Other than Neonatal & 410 & 376 & 204 & 155 & 177 & 107 & 333 & 393 & \\
\hline Urinary Tract Infections-OPDDH & & 10 & 16 & 9 & 0 & 39 & 63 & 82 & \\
\hline Eye Infections-Others-IMCI & 138 & 139 & 44 & 5 & 0 & 9 & & & \\
\hline Eye Problem Other & 475 & 366 & 678 & 124 & & & & & \\
\hline Eye Problem Other-OPD New & & & & 222 & 395 & 1208 & 49 & 275 & 138 \\
\hline IMCI-Eye Problems & & & & & & & 12 & 266 & 160 \\
\hline OPD-Total Eye Cases Consulted or Screened & & & & & & & 27 & 411 & 147 \\
\hline Acute Respiratory Infection Other-Hosp & 22 & 27 & 19 & 15 & 30 & 1 & 8 & 3 & \\
\hline HOSP-Other Respiratory Diseases & & & & & & & & 5 & 1 \\
\hline IMCI-Other Respiratory Diseases & & & & & & & 0 & 122 & 202 \\
\hline OPD Acute Respiratory Disease Other & & & & & & & 91 & 10,893 & 7290 \\
\hline Severe Pneumonia or Very Severe Respiratory Disease & 0 & 0 & 338 & 0 & 0 & 31 & 0 & 0 & \\
\hline
\end{tabular}

abnormalities appear after long term exposure to air pollutants. Priscila el al. reported that exposure of the ocular on traffic pollution resulted in discomfort and tear breakup symptoms, in this research they indicated Ocular mucosa as bioindicator of exposure to air pollution (Novaes, do Nascimento Saldiva et al., 2010; Torricelli, Novaes et al., 2013).

Table 4 presents the visit of patients at Kibagabaga Hospital and different illness identified such as Respiratory, skin infection and other related illness. Previous research reported respiratory disease to be associated to the air pollution (Zhang, Li et al., 2011; Gao, Chan et al., 2014). The study revealed that the community in Ndera sector experienced some challenges related to liver and lung disease (Table 3), previous research illustrated that air pollution can contribute to diabetes and liver disease in the community (Conklin, 2013).

Figure 2 illustrated that high number of patients recorded at the hospital presented the asthma symptoms, the people in the community believe asthma to be 
directly associated with air pollution as wells, previous research reported asthma to be related to air pollution (Lovinsky-Desir, Acosta et al., 2019). The high number of patients recorded at the hospital during the period from 2009 to 2010 with OPD Acute respiratory disease and HOSP other respiratory diseases were influenced by the high concentration of air pollution, The ANOVA analysis indicated that there is significant different between health risks with $(p=0.00)$ and air pollution $(p=0.00)$. It was also found the there was a high degree of positive correlation between training given to air pollution and health risk where Karl Pearson coefficient of correlation ( $\mathrm{r}$ ) was 0.703 , this implies that air pollution contributed to the health problem revealed in Ndera community especially in industry zone and its relationship is positively at a high level.

\subsection{Correlation between Air Pollution and Mental Stress}

The residents in Ndera have experienced and persistent air pollution from industrial activities. Previous epidemiological studies have illustrated that exposure to $\mathrm{PM}_{2.5}$ and $\mathrm{PM}_{10}$ are associated with increased risk of mortality and morbidity (Smith \& Mehta, 2003; Atkinson, Kang et al., 2014), even at low levels, and millions of people died of air pollution particulate (Rohde \& Muller, 2015).

Air pollution has been indicated to have a diverse negative impact on public health and according to previous study; living in an area with significant air pollution can negatively impact mental health (Tsuang, 2000).

Previous study illustrated significant associations between air pollution and rates of psychiatric and neuropsychiatric disorders (Khan, Plana-Ripoll et al., 2019). The researchers have identified bipolar disorder and depression in people living in areas with poor air quality. Epilepsy has been reported to be associated with air pollution (Cakmak, Dales et al., 2010). It has been also identified in Ndera (Figure 2).

Figure 2 indicated the high number of patients attended the hospital presented

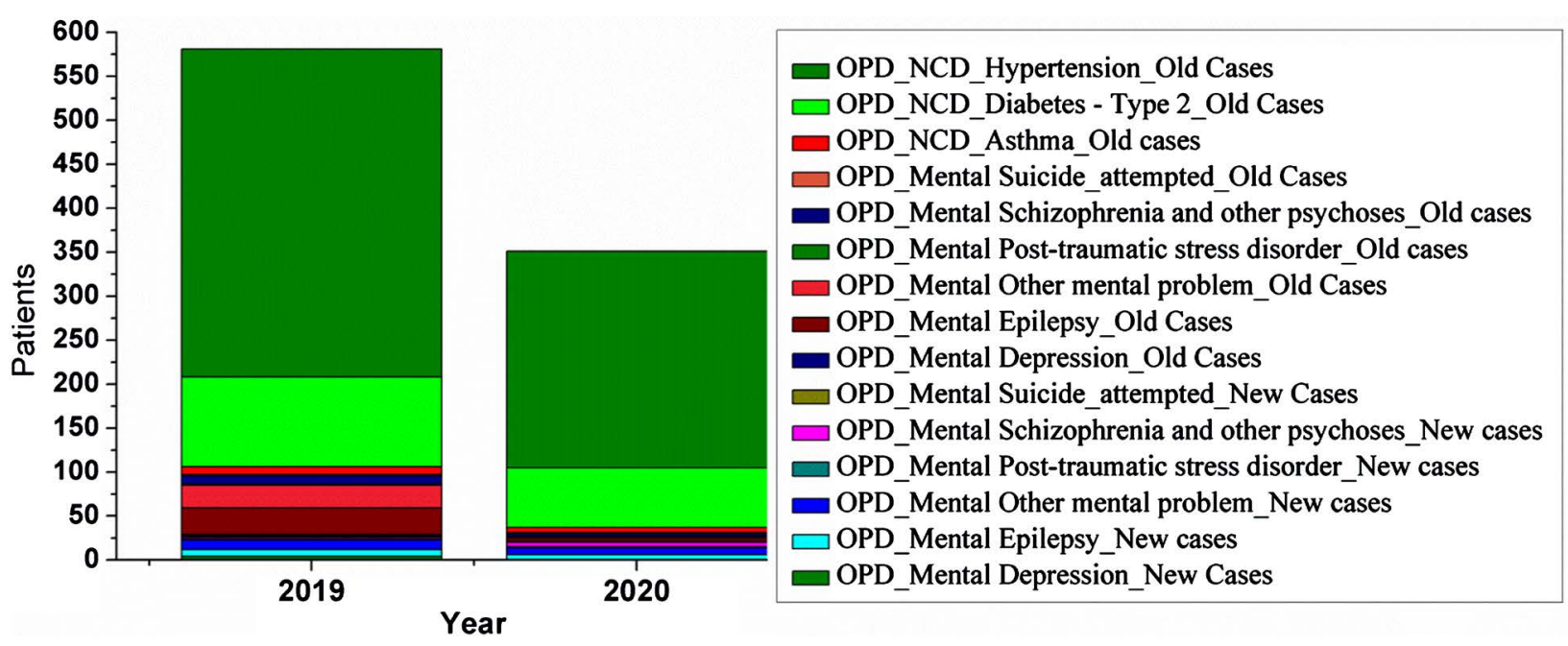

Figure 2. Mental disorders and other related illness identified from Ndera patients at the hospital. 
the symptoms of mental stress which were associated to air pollution in the study areas.

The intensity of the patients received at the hospital during the period from 2019 and 2020 with the cases of metal stress were high compared to other cases such as Asthma (Table 5). This frequency of patients led to conclude that such illnesses were related to air pollution due to the fact that no other causes were identified. However, the peaks were shown to be high with diabetes and hypertension and these were also associated with air pollution previously (Conklin, 2013).

\subsection{Source of Air Pollution and Distribution in Ndera}

Human activity produces mixtures of pollutants in indoor and outdoor air (Guarnieri \& Balmes, 2014), the study revealed that in Ndera sector, there are many source of air pollution such as air traffic emission as main source of particulate matter of $\mathrm{PM}_{2.5}$ and $\mathrm{PM}_{10}$ (Table 6), which has been investigated in previous research(Artınano, Salvador et al., 2004).

Table 6 illustrated the percentage of $98.2 \%$ of respondents which confirmed that industrial activities in areas of Ndera are suspected to be source of the Carbon monoxide and carbon dioxide pollution, the literature cited that the sources of $\mathrm{CO}_{2}$ emissions are attributed to various factors such as different fuel efficiency, production techniques, consumption patterns and Industrial activities (Chung, 1998). The respondents questioned illustrated that $96.10 \%$ of pollution

Table 5. Mental and other illness reported by the hospital and were associated to the air pollution.

\begin{tabular}{|c|c|c|}
\hline Period & 2019 & 2020 \\
\hline OPD-Mental Depression-New Cases & 4 & 0 \\
\hline OPD-Mental Epilepsy-New Cases & 8 & 6 \\
\hline OPD-Mental Other Mental Problem-New Cases & 11 & 8 \\
\hline OPD-Mental Post-Traumatic Stress Disorder-New Cases & 1 & 1 \\
\hline OPD-Mental Schizophrenia and Other Psychoses-New Cases & 2 & 5 \\
\hline OPD-Mental Suicide-Attempted-New Cases & 1 & 1 \\
\hline OPD-Mental Depression-Old Cases & 2 & 0 \\
\hline OPD-Mental Epilepsy-Old Cases & 30 & 3 \\
\hline OPD-Mental Other Mental Problem-Old Cases & 26 & 2 \\
\hline OPD-Mental Post-Traumatic Stress Disorder-Old Cases & 1 & 1 \\
\hline OPD-Mental Schizophrenia and Other Psychoses-Old Cases & 10 & 3 \\
\hline OPD-Mental Suicide-Attempted-Old Cases & 1 & 1 \\
\hline OPD-NCD-Asthma-Old Cases & 9 & 6 \\
\hline OPD-NCD-Diabetes-Type 2-Old Cases & 102 & 68 \\
\hline OPD-NCD-Hypertension-Old Cases & 373 & 246 \\
\hline
\end{tabular}


Table 6. Respondent confirmation of source of air pollution.

\begin{tabular}{cccccccc}
\hline & \multicolumn{2}{c}{ Disagree } & \multicolumn{2}{c}{ Neutral } & \multicolumn{2}{c}{ Agree } \\
\cline { 2 - 7 } Parameters & Frequency & $\%$ & Frequency & $\%$ & Frequency & $\%$ \\
\hline $\begin{array}{c}\text { Motor engines are the source of } \\
\mathrm{PM}_{2.5} \text { and } \mathrm{PM}_{10}\end{array}$ & 11 & 4.5 & 1 & 0.4 & 225 & 94.8 \\
$\begin{array}{c}\text { Vehicular exhaust are the main } \\
\text { source of ground level ozone }\end{array}$ & 7 & 2.9 & 1 & 0.4 & 237 & 96.7 \\
$\begin{array}{c}\text { Industrial activities are main } \\
\text { pollutant from the carbon }\end{array}$ & 4 & 11.6 & 0 & 0 & 233 & 98.2 \\
$\begin{array}{c}\text { monoxide and carbon dioxide } \\
\text { Fuel combustion produce the } \\
\text { Sulfur dioxide }\end{array}$ & 14 & 5.8 & 9 & 3.7 & 213 & 89.2 \\
$\begin{array}{c}\text { Wood fires cause polycyclic } \\
\text { aromatic hydrocarbons }\end{array}$ & 7 & 2.94 & 2 & 0.8 & 228 & 96.1 \\
\hline
\end{tabular}

D: Disagree, N: Neutral, A: Agree, PM = Particulate matter.

is generated from fire wood which affects the community, this source of pollution has been confirmed with may research(Van Houdt, Daenen et al., 1986; Zou, Zhang et al., 2003).

\section{Conclusion}

The main focus of this research was to assess the impact of air pollution on the community health in Masoro cell in Ndera Sector. The findings revealed that the air pollution in Masoro is associated with major problems that affected the community health with different illness. Findings illustrated that a great part of emission comes from industry, related activities and vehicles. Respiratory related disease was reported to be the main illness identified in Masoro community. The findings from the hospital recorded illness illustrated that the hypertension and diabetes dominated the illness in community due to different kinds of pollution. The respondents confirmed that the community are aware of pollution and are experiencing the consequences of pollution such as cancer and other complicated illness. While conducting this study, the time was not enough to reach different point of this research such as analysis of field sample in laboratory and determine different types of pollution released by industrial zone, to correlate them with the evidence collected from the hospital and information provided with the respondents; this is open for future research.

\section{Conflicts of Interest}

The authors declare no conflicts of interest.

\section{References}

Ajayi, O. C., Akinnifesi, F. K., Sileshi, G., \& Chakeredza, S. (2007). Adoption of Renewable Soil Fertility Replenishment Technologies in the Southern African Region: Lessons Learnt and the Way Forward. Natural Resources Forum, 31, 306-317. 
https://doi.org/10.1111/j.1477-8947.2007.00163.x

Artınano, B., Salvador, P., Alonso, D., Querol, X., \& Alastuey, A. (2004). Influence of Traffic on the $\mathrm{PM}_{10}$ and $\mathrm{PM}_{2.5}$ Urban Aerosol Fractions in Madrid (Spain). Science of the Total Environment, 334, 111-123. https://doi.org/10.1016/j.scitotenv.2004.04.032

Ashmore, M., \& Dimitroulopoulou, C. (2009). Personal Exposure of Children to Air Pollution. Atmospheric Environment, 43, 128-141.

https://doi.org/10.1016/j.atmosenv.2008.09.024

Atkinson, R., Kang, S., Anderson, H., Mills, I., \& Walton, H. (2014). Epidemiological Time Series Studies of $\mathrm{PM}_{2.5}$ and Daily Mortality and Hospital Admissions: A Systematic Review and Meta-Analysis. Thorax, 69, 660-665.

https://doi.org/10.1136/thoraxjnl-2013-204492

Azumah, S. B., Donkoh, S. A., \& Awuni, J. A. (2018). The Perceived Effectiveness of Agricultural Technology Transfer Methods: Evidence from Rice Farmers in Northern Ghana. Cogent Food \& Agriculture, 4, Article ID: 1503798.

https://doi.org/10.1080/23311932.2018.1503798

Bai, R., Guan, L., Zhang, W., Xu, J., Rui, W., Zhang, F., \& Ding, W. (2016). Comparative Study of the Effects of PM1-Induced Oxidative Stress on Autophagy and Surfactant Protein B and C Expressions in Lung Alveolar Type II Epithelial MLE-12 Cells. Biochimica et Biophysica Acta (BBA)-General Subjects, 1860, 2782-2792.

https://doi.org/10.1016/j.bbagen.2016.05.020

Bickerstaff, K., \& Walker, G. (2003). The Place(s) of Matter: Matter out of Place-Public Understandings of Air Pollution. Progress in Human Geography, 27, 45-67. https://doi.org/10.1191/0309132503ph412oa

Bowatte, G., Lodge, C., Lowe, A. J., Erbas, B., Perret, J., Abramson, M. J., Matheson, M., \& Dharmage, S. C. (2015). The Influence of Childhood Traffic-Related Air Pollution Exposure on Asthma, Allergy and Sensitization: A Systematic Review and a Meta-Analysis of Birth Cohort Studies. Allergy, 70, 245-256. https://doi.org/10.1111/all.12561

Cakmak, S., Dales, R. E., \& Vidal, C. B. (2010). Air Pollution and Hospitalization for Epilepsy in Chile. Environment International, 36, 501-505.

https://doi.org/10.1016/j.envint.2010.03.008

Chung, H.-S. (1998). Industrial Structure and Source of Carbon Dioxide Emissions in East Asia: Estimation and Comparison. Energy \& Environment, 9, 509-533. https://doi.org/10.1177/0958305X9800900505

Cohen, A. J., Ross Anderson, H., Ostro, B., Pandey, K. D., Krzyzanowski, M., Künzli, N., Gutschmidt, K., Pope, A., Romieu, I., \& Samet, J. M. (2005). The Global Burden of Disease Due to Outdoor Air Pollution. Journal of Toxicology and Environmental Health, Part A, 68, 1301-1307. https://doi.org/10.1080/15287390590936166

Conklin, D. J. (2013). From Lung to Liver: How Does Airborne Particulate Matter Trigger NASH and Systemic Insulin Resistance? Journal of Hepatology, 58, 8-10. https://doi.org/10.1016/j.jhep.2012.10.008

Gao, Y., Chan, E. Y., Li, L., Lau, P. W., \& Wong, T. W. (2014). Chronic Effects of Ambient Air Pollution on Respiratory Morbidities among Chinese Children: A Cross-Sectional Study in Hong Kong. BMC Public Health, 14, Article No. 105.

https://doi.org/10.1186/1471-2458-14-105

Ghorani-Azam, A., Riahi-Zanjani, B., \& Balali-Mood, M. (2016). Effects of Air Pollution on Human Health and Practical Measures for Prevention in Iran. Journal of Research in Medical Sciences, 21, 65. https://doi.org/10.4103/1735-1995.189646

Guarnieri, M., \& Balmes, J. R. (2014). Outdoor Air Pollution and Asthma. The Lancet, 383, 
1581-1592. https://doi.org/10.1016/S0140-6736(14)60617-6

Gül, H., Gaga, E. O., Döğeroğlu, T., Özden, Ö., Ayvaz, Ö., Özel, S., \& Güngör, G. (2011). Respiratory Health Symptoms among Students Exposed to Different Levels of Air Pollution in a Turkish City. International Journal of Environmental Research and Public Health, 8, 1110-1125. https://doi.org/10.3390/ijerph8041110

Gupta, S. K., Gupta, V., Joshi, S., \& Tandon, R. (2002). Subclinically Dry Eyes in Urban Delhi: An Impact of Air Pollution? Ophthalmologica, 216, 368-371. https://doi.org/10.1159/000066183

Gupta, S., Gupta, S., Agarwal, R., Sushma, S., Agrawal, S., \& Saxena, R. (2007). A Multicentric Case-Control Study on the Impact of Air Pollution on Eyes in a Metropolitan City of India. Indian Journal of Occupational and Environmental Medicine, 11, 37-40. https://doi.org/10.4103/0019-5278.32463

Henninger, S. M. (2013). When Air Quality Becomes Deleterious-A Case Study for Kigali, Rwanda. Journal of Environmental Protection, 4, 1-7. https://doi.org/10.4236/jep.2013.48A1001

Hunter, P. R., Davies, M. A., Hill, K., Whittaker, M., \& Sufi, F. (2003). The Prevalence of Self-Reported Symptoms of Respiratory Disease and Community Belief about the Severity of Pollution from Various Sources. International Journal of Environmental Health Research, 13, 227-238. https://doi.org/10.1080/0960312031000122389

Kamarudeen, S., \& Söderbom, M. (2013). Constraints and Opportunities in Rwanda's Industrial Sector. IGC Working Paper.

Kan, H., Chen, B., \& Hong, C. (2009). Health Impact of Outdoor Air Pollution in China: Current Knowledge and Future Research Needs. National Institute of Environmental Health Sciences.

Khafaie, M. A., Yajnik, C. S., Salvi, S. S., \& Ojha, A. (2016). Critical Review of Air Pollution Health Effects with Special Concern on Respiratory Health. Journal of Air Pollution and Health, 1, 123-136.

Khan, A., Plana-Ripoll, O., Antonsen, S., Brandt, J., Geels, C., Landecker, H., Sullivan, P. F., Pedersen, C. B., \& Rzhetsky, A. (2019). Environmental Pollution Is Associated with Increased Risk of Psychiatric Disorders in the US and Denmark. PLoS Biology, 17, e3000353. https://doi.org/10.1371/journal.pbio.3000353

Kim, K.-H., Kabir, E., \& Kabir, S. (2015). A Review on the Human Health Impact of Airborne Particulate Matter. Environment International, 74, 136-143. https://doi.org/10.1016/j.envint.2014.10.005

Kumar, S. (2004). Occupational Exposure Associated with Reproductive Dysfunction. Journal of Occupational Health, 46, 1-19. https://doi.org/10.1539/joh.46.1

Liu, Y., Chen, X., Huang, S., Tian, L., Lu, Y. A., Mei, Y., Ren, M., Li, N., Liu, L., \& Xiang, H. (2015). Association between Air Pollutants and Cardiovascular Disease Mortality in Wuhan, China. International Journal of Environmental Research and Public Health, 12, 3506-3516. https://doi.org/10.3390/ijerph120403506

Lovinsky-Desir, S., Acosta, L. M., Rundle, A. G., Miller, R. L., Goldstein, I. F., Jacobson, J. S., Chillrud, S. N., \& Perzanowski, M. S. (2019). Air Pollution, Urgent Asthma Medical Visits and the Modifying Effect of Neighborhood Asthma Prevalence. Pediatric Research, 85, 36-42. https://doi.org/10.1038/s41390-018-0189-3

Nel, A. (2005). Air Pollution-Related Illness: Effects of Particles. Science, 308, 804-806. https://doi.org/10.1126/science.1108752

Neuberger, M., Moshammer, H., \& Rabczenko, D. (2013). Acute and Subacute Effects of Urban Air Pollution on Cardiopulmonary Emergencies and Mortality: Time Series Stud- 
ies in Austrian Cities. International Journal of Environmental Research and Public Health, 10, 4728-4751. https://doi.org/10.3390/ijerph10104728

Novaes, P., do Nascimento Saldiva, P. H., Matsuda, M., Macchione, M., Rangel, M. P., Kara-José, N., \& Berra, A. (2010). The Effects of Chronic Exposure to Traffic Derived Air Pollution on the Ocular Surface. Environmental Research, 110, 372-374. https://doi.org/10.1016/j.envres.2010.03.003

Nsengimana, H., Bizimana, J., \& Sezirahiga, Y. (2011). A Study on Air Pollution in Rwanda with Reference to Kigali City and Vehicular Emissions. REMA, BUTARE.

Patel, S., Ramaiah Nellore, M. R., Sadhu, H. G., Kulkarni, P. K., Patel, B. D., \& Parikh, D. J. (2008). Effects of Industrial Pollution on Respiratory Morbidity among Female Residents of India. Archives of Environmental \& Occupational Health, 63, 87-92. https://doi.org/10.3200/AEOH.63.2.87-92

Pope III, C. A., Burnett, R. T., Thurston, G. D., Thun, M. J., Calle, E. E., Krewski, D., \& Godleski, J. J. (2004). Cardiovascular Mortality and Long-Term Exposure to Particulate Air Pollution: Epidemiological Evidence of General Pathophysiological Pathways of Disease. Circulation, 109, 71-77. https://doi.org/10.1161/01.CIR.0000108927.80044.7F

Pope III, C. A., Burnett, R. T., Turner, M. C., Cohen, A., Krewski, D., Jerrett, M., Gapstur, S. M., \& Thun, M. J. (2011). Lung Cancer and Cardiovascular Disease Mortality Associated with Ambient Air Pollution and Cigarette Smoke: Shape of the Exposure-Response Relationships. Environmental Health Perspectives, 119, 1616-1621.

Roemer-Mahler, A. (2006). The Power of Knowledge: CSOs and Environmental Policy Making in South Africa. Research and Policy in Development (RAPID).

Rohde, R. A., \& Muller, R. A. (2015). Air Pollution in China: Mapping of Concentrations and Sources. PLoS ONE, 10, e0135749. https://doi.org/10.1371/journal.pone.0135749

Salvi, S. (2007). Health Effects of Ambient Air Pollution in Children. Paediatric Respiratory Reviews, 8, 275-280. https://doi.org/10.1016/j.prrv.2007.08.008

Saxena, R., Srivastava, S., Trivedi, D., Anand, E., Joshi, S., \& Gupta, S. K. (2003). Impact of Environmental Pollution on the Eye. Acta Ophthalmologica Scandinavica, 81, 491-494. https://doi.org/10.1034/j.1600-0420.2003.00119.x

Scott, G. M., \& Diab, R. D. (2000). Forecasting Air Pollution Potential: A Synoptic Climatological Approach. Journal of the Air \& Waste Management Association, 50, 1831-1842. https://doi.org/10.1080/10473289.2000.10464216

Slovin, E. (1960). Slovin's Formula for Sampling Technique.

Smith, K. R., \& Mehta, S. (2003). The Burden of Disease from Indoor Air Pollution in Developing Countries: Comparison of Estimates. International Journal of Hygiene and Environmental Health, 206, 279-289. https://doi.org/10.1078/1438-4639-00224

Torricelli, A. A., Novaes, P., Matsuda, M., Braga, A., Saldiva, P. H., Alves, M. R., \& Monteiro, M. L. (2013). Correlation between Signs and Symptoms of Ocular Surface Dysfunction and Tear Osmolarity with Ambient Levels of Air Pollution in a Large Metropolitan Area. Cornea, 32, e11-e15.

https://doi.org/10.1097/ICO.0b013e31825e845d

Tsuang, M. (2000). Schizophrenia: Genes and Environment. Biological Psychiatry, 47, 210-220. https://doi.org/10.1016/S0006-3223(99)00289-9

Uwayo, P., Nsanzumukiza, V. M., Maniragaba, A., Nsabimana, A. P., \& Akimanizanye, V. (2020). Contribution of Former Poachers for Wildlife Conservation in Rwanda Volcanoes National Park. Journal of Geoscience and Environment Protection, 8, 47-56. https://doi.org/10.4236/gep.2020.84004

Van Houdt, J., Daenen, C., Boleij, J., \& Alink, G. (1986). Contribution of Wood Stoves 
and Fire Places to Mutagenic Activity of Airborne Particulate Matter Inside Homes. Mutation Research/Genetic Toxicology, 171, 91-98.

https://doi.org/10.1016/0165-1218(86)90040-6

West, S. K., Bates, M. N., Lee, J. S., Schaumberg, D. A., Lee, D. J., Adair-Rohani, H., Chen, D. F., \& Araj, H. (2013). Is Household Air Pollution a Risk Factor for Eye Disease? International Journal of Environmental Research and Public Health, 10, 5378-5398. https://doi.org/10.3390/ijerph10115378

Wong, C.-M., Ou, C.-Q., Chan, K.-P., Chau, Y.-K., Thach, T.-Q., Yang, L., Chung, R. Y.-N., Thomas, G. N., Peiris, J. S. M., \& Wong, T.-W. (2008). The Effects of Air Pollution on Mortality in Socially Deprived Urban Areas in Hong Kong, China. Environmental Health Perspectives, 116, 1189-1194.

Zhang, F., Li, L., Krafft, T., Lv, J., Wang, W., \& Pei, D. (2011). Study on the Association between Ambient Air Pollution and Daily Cardiovascular and Respiratory Mortality in an Urban District of Beijing. International Journal of Environmental Research and Public Health, 8, 2109-2123. https://doi.org/10.3390/ijerph8062109

Zhang, F., Wang, W., Lv, J., Krafft, T., \& Xu, J. (2011). Time-Series Studies on Air Pollution and Daily Outpatient Visits for Allergic Rhinitis in Beijing, China. Science of the Total Environment, 409, 2486-2492. https://doi.org/10.1016/j.scitotenv.2011.04.007

Zou, L. Y., Zhang, W., \& Atkiston, S. (2003). The Characterisation of Polycyclic Aromatic Hydrocarbons Emissions from Burning of Different Firewood Species in Australia. Environmental Pollution, 124, 283-289. https://doi.org/10.1016/S0269-7491(02)00460-8 